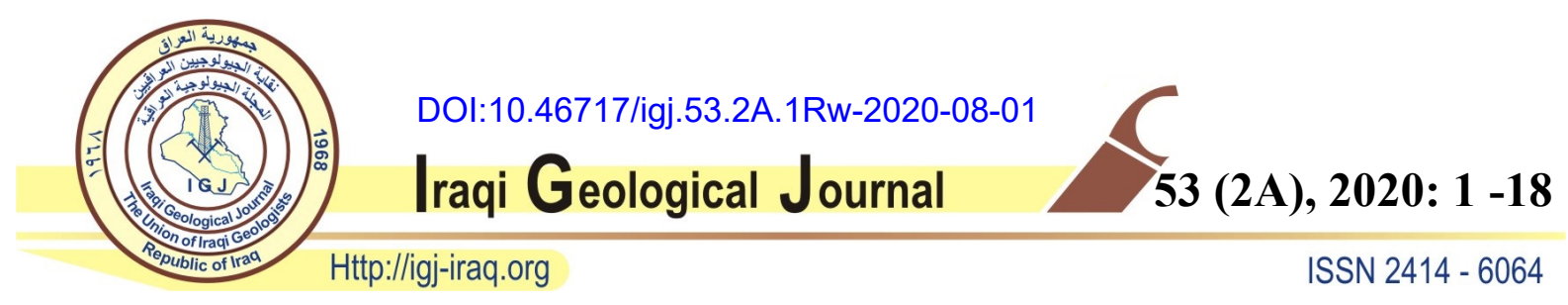

\title{
HYDROCHEMICAL EVALUATION OF THE AZRAQ UNCONFINED AQUIFER, JORDAN
}

\author{
${ }^{1}$ Sura Al-Harahshah ${ }^{*},{ }^{2 \& 3}$ Marwan Al-Raggad, ${ }^{4}$ Ahmad Al-Shdaifat and ${ }^{5}$ Mohammad Al- \\ Wreikat \\ ${ }^{1}$ Institute of Earth and Environmental Sciences, Al Al-Bayt University, Mafraq, Jordan \\ ${ }^{2}$ Water, Energy and Environment Center, University of Jordan, Amman, Jordan \\ ${ }^{3}$ Inter-Islamic Network on Water Resources Development and Management (INWRDAM), Amman, Jordan \\ ${ }^{4}$ School of Geography, University of Nottingham, Nottingham NG7 2RD, UK \\ ${ }^{5}$ Ministry of Water and Irrigation, Amman, Jordan \\ *E-mail:sura@aabu.edu.jo \\ Received: 8 April 2020; accepted: 28 June 2020
}

\begin{abstract}
The groundwater hydrochemical characteristics of the Azraq Basin were investigated and evaluated statistically. The presence of an underground saline water body in the Qa' AlAzraq area has made this specific part of the basin. 38 samples from $38 \mathrm{GW}$ wells were collected to understand the GW hydrochemistry of the Azraq unconfined aquifer that is mainly composed of marl, evaporites, limestone and clay formations. The PCA analysis indicates that $\mathrm{Na}, \mathrm{Mg}, \mathrm{Cl}, \mathrm{Ca}$, and $\mathrm{K}$ contribute the variance in the chemical composition of the $G W$ samples. Piper, Durov and Wilcox diagrams indicated that the water types are mainly earth alkaline with prevailing $\mathrm{SO}_{4}$ and $\mathrm{Cl}$, and alkaline water with prevailing $\mathrm{SO}_{4}$ and $\mathrm{Cl}$. The main processes in the basin are dissolution or mixing and reverse ion exchange in which $\mathrm{Na}$ and $\mathrm{Cl}$ are prevailing. The $\mathrm{GW}$ is mainly oversaturated concerning aragonite, calcite and dolomite as indicated by the excess input of Mg and Ca ions from the rock-water interactions, while anhydrite $\left(\mathrm{CaSO}_{4}\right)$, halite $(\mathrm{NaCl})$, and gypsum $\left(\mathrm{CaSO}_{4} \cdot 2 \mathrm{H}_{2} \mathrm{O}\right)$ are generally undersaturated. The effect of the agricultural activities in the study area is reflected by the positive correlation between $\mathrm{NO}_{3}$ and $\mathrm{PC}_{2}$.Wilcox diagram indicates that the samples are in the medium to very high salinity slots with the majority in the high salinity slot and in the low and medium alkali hazard zone, while few samples show high to very high alkali hazards. The simulated salinity for the next 30 years shows alarming danger and requires immediate attention as the Qa' area is expected to become saline with TDS values of 2500 to $4600 \mathrm{mg} /$, unsuitable to use for domestic and/or agricultural purposes.
\end{abstract}

Keywords: Jordan; Groundwater; Azraq Basin; Hydrochemistry; Aquifer 


\section{INTRODUCTION}

The water demand in the Arab Peninsula region rises as a result of population growth in its country as it was considered one of the highest in the world (Awadh et al., 20182020). The geographical location of Jordan and the complex orography generate a rather complex climatic and environmental setting from the northwestern and central highlands to the central plateau, and the eastern and southern deserts (Fig. 1). The topography influences a north-south, westeast gradient of precipitation and temperature. Because of the rapid increase in population in Jordan, attributed to normal population growth rates and refugee crises (Al-Karablieh and Salman, 2016) and the projected climate change and decreased precipitation In general, water usage is a factor of its quality (Ibrahim, 2018), and it is well established that the geological settings play a significant role in determining the groundwater composition, mainly through rock-water interactions (Möller et al., 2020; Ibrahim and El-Naqa, 2018). When water moves through various geological formations, minerals are precipitated and/or ions are exchanged. In Jordan, 12 main groundwater basins are presented and groundwater represents the main source of fresh water, accounting for more than $65 \%$ of the total $900 \mathrm{MCM}$ of fresh water supplied through a given year. This necessitates the need for a better understanding of the nature of groundwater, its long-term availability and limitations (Ibrahim, 2018). One of the main groundwater basins in Jordan is the Azraq Basin, located in the northeastern part of Jordan and extending northward into Syria (ca. 5\% of total basin area) and southward into Saudi Arabia (ca. 1\% of total basin area) (Fig. 1). Qa' Al-Azraq, the central part of the basin (Figs. 1 and 4) is the focus area of this study. Several studies have reported quality deterioration in the Azraq Basin groundwater and severe level drop due to overexploitation and anthropological activities. The presence of a saline water body in Qa' Al-Azraq is influenced this study to focus on this area where accelerated deterioration of the groundwater is documented both by the groundwater samples in the previous studies and the salt accumulations on the Qa' floor and around the Azraq wetland reserve (Fig. 1) (INWRDAM, 2019; Ibrahim and El-Naqa, 2018). Heterogeneity is characteristic groundwater which is generally characterized by high $\mathrm{Mg}$ content, some wells produce water permissible for both irrigation and potable uses whereas other is only suitable for irrigation (Awadh, 2018). (Yaseen et al., 2018) proposed a model for forecasting monthly river flow, the model helps in the prediction of river flow for shorter time scale such as daily or hourly river flow can be explored. (Jirjees et al., 2020) mentioned that the rainfall of winter and spring are the most effective for the creation of discharge in the area. Surface runoff is about $\%$ 30.4 of the rainfall and groundwater recharge of the area is about $\% 26.2$ of the rainfall. 
Accordingly, this study aims to evaluate the hydrochemical characteristics of the groundwater in and around the Qa' Al-Azraq area and to shed light on its chemistry and genesis. Furthermore, this study aims to provide a better understanding in terms of future projection of the salinity increasing trends in the area and the consequent implications on the ecosystem.

\section{STUDY AREA CHARACTERISTICS}

The Azraq catchment spreads over an area of ca. $12710 \mathrm{~km}^{2}$. The area as a whole is considered to be arid to semiarid, reflected by the mean annual rainfall of ca. $87 \mathrm{~mm} / \mathrm{yr}$, while precipitation is ca. $50 \mathrm{~mm} / \mathrm{yr}$ over the central parts of the catchment and rises to ca.

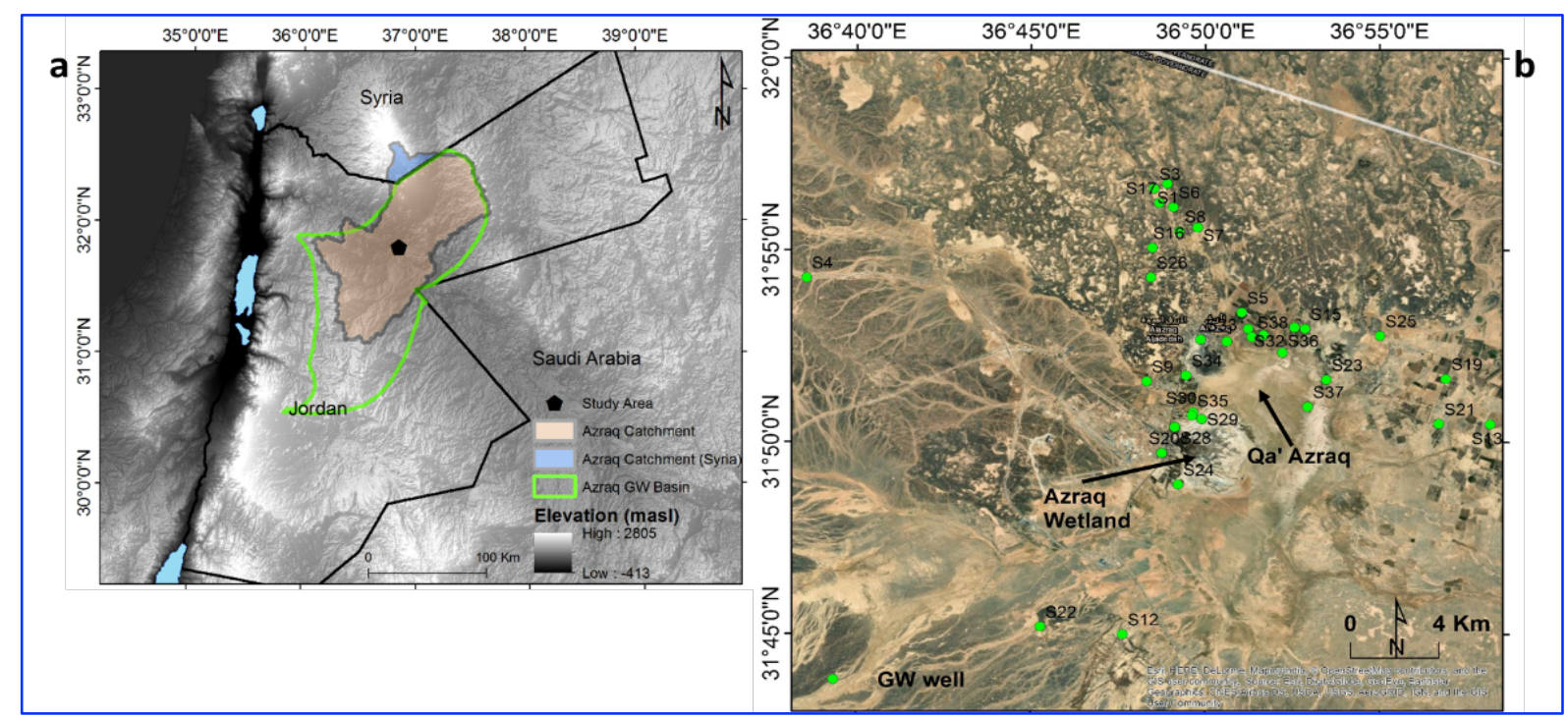

Fig. 1. (a) Azraq Basin location showing the study area (b) Google Earth image showing the salt accumulations (light white colour) in and around Qa' Al Azraq and the location of the investigated GW wells (green circles)

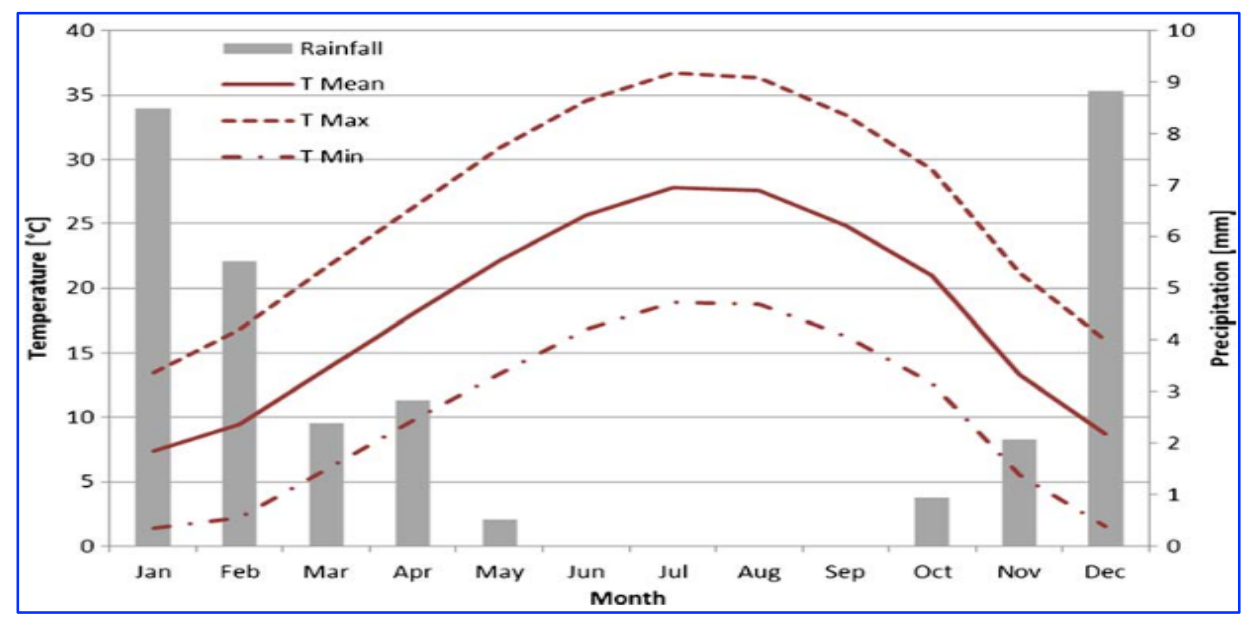

Fig. 2. Azraq Basin annual temperature and rainfall (after Ibrahim and El-Naqa, 2018) 
$500 \mathrm{~mm} / \mathrm{yr}$ over the high summit of the Druze Mountain (Ibrahim and El-Naqa, 2018). Average annual temperatures are $11.6^{\circ} \mathrm{C}$ and $26.6^{\circ} \mathrm{C}$ for winter and summer seasons, respectively. The climate settings of the basin are mainly characterized by hot summers and wet winters (Fig. 2). The topographical controls of the catchment area are represented by the $1,550 \mathrm{~m}$ above sea level (a.s.l). Jabal Druz in the north and the ca. $500 \mathrm{~m}$ hills in the south, west, and east. The surface water flows into the Qa' Al-Azraq through several wide shallow wadis (Fig. 3). The Azraq Basin is believed to have formed during the period from the Late Cretaceous to Quaternary, comprising both igneous and sedimentary rock exposures and sequences. The main sedimentary rocks within the basin are primarily composed of limestone, chert, clay, marl, sandstone, and evaporites. The Rijam and Wadi shallalla sedimentary formations are found in the eastern and central parts of the Azraq Basin, whereas the northern part is dominated by basalts (Ibrahim, 1996). The aquifer system in the Azraq Basin is illustrated in Fig. 3b. The upper aquifer, the main aquifer in the Azraq Basin, is an unconfined four-member aquifer, mainly comprised of Quaternary alluvial sediments, Basalts, B4 and B5. The Basalt aquifer is hydraulically connected to the $\mathrm{B} 4$ aquifer (Table1) and the groundwater moves from the basin margins towards the Qa' Al-Azraq (Fig. 4).

\section{SAMPLING AND METHODOLOGY}

The presence of an underground saline water body underlying the Qa' Al-Azraq area (INWRDAM, 2019; Ibrahim and El-Naqa, 2018) influenced this investigation to focus on groundwater wells surrounding the Qa' Al-Azraq. Groundwater samples were collected from 38 groundwater wells in an attempt to cover the area surrounding Qa' Al-Azraq (Fig. 3 and Table 2). Sampling was done using silica bottles as per accredited standards. To ensure representative water sampling, two to four hours washout time were considered before sampling. Samples were stored at $4^{\circ} \mathrm{C}$ and analyzed in less than 72 hours of collection. The collected groundwater samples were examined for the major anions and cations, acidity $(\mathrm{pH})$, and electrical conductance (Tables 3 and 4). Fieldwork observations were used as a first order understanding of the system. Then, the water samples were analyzed and statistically evaluated using descriptive statistics and Pearson correlations (Excel 2013 software) to draw a preliminary understanding of the water composition and the effects of the system. To understand the variance in the GW composition, a PCA analysis was conducted using R software (Factoextra and FactoMiner packages). PCA is a useful tool in explaining the variance in a set of parameters and outlining the main contributors to this variance. 


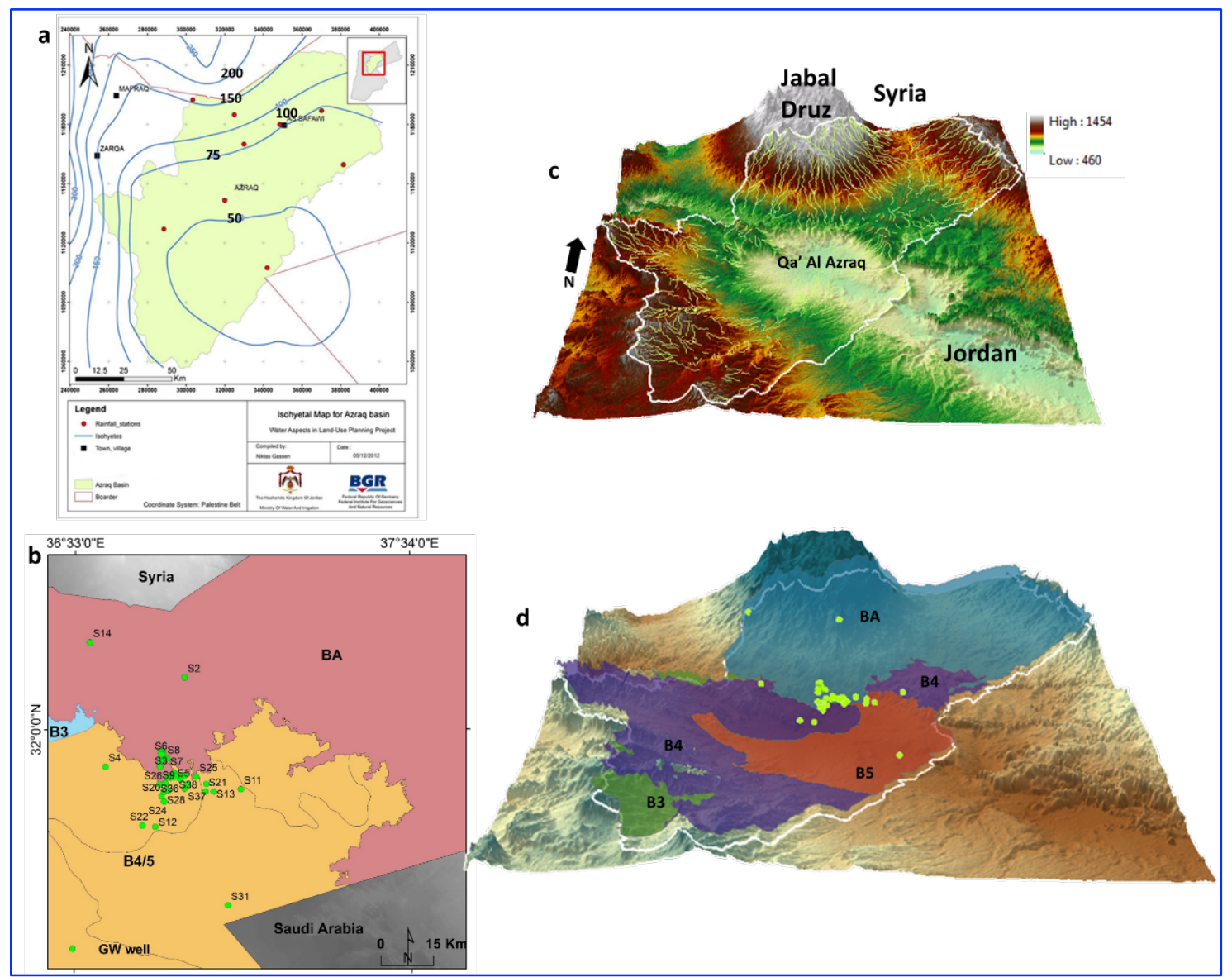

Fig. 3. (a) Isohyetal lines of Azraq Basin (from Steinel, 2012) (b) the main aquifers in the Azraq Basin and the location of the investigated GW wells (green circles). BA: Basalt aquifer, B3: Muwaqar limestone aquiclude, B4: Um Rijam limestone aquifer, B5: Wadi el Shallala aquiclude (Data from Ibrahim, 1996). (c) 3D representation of the Azraq Basin (white polygon) overlain by the drainage system and the main aquifers in the Azraq Basin

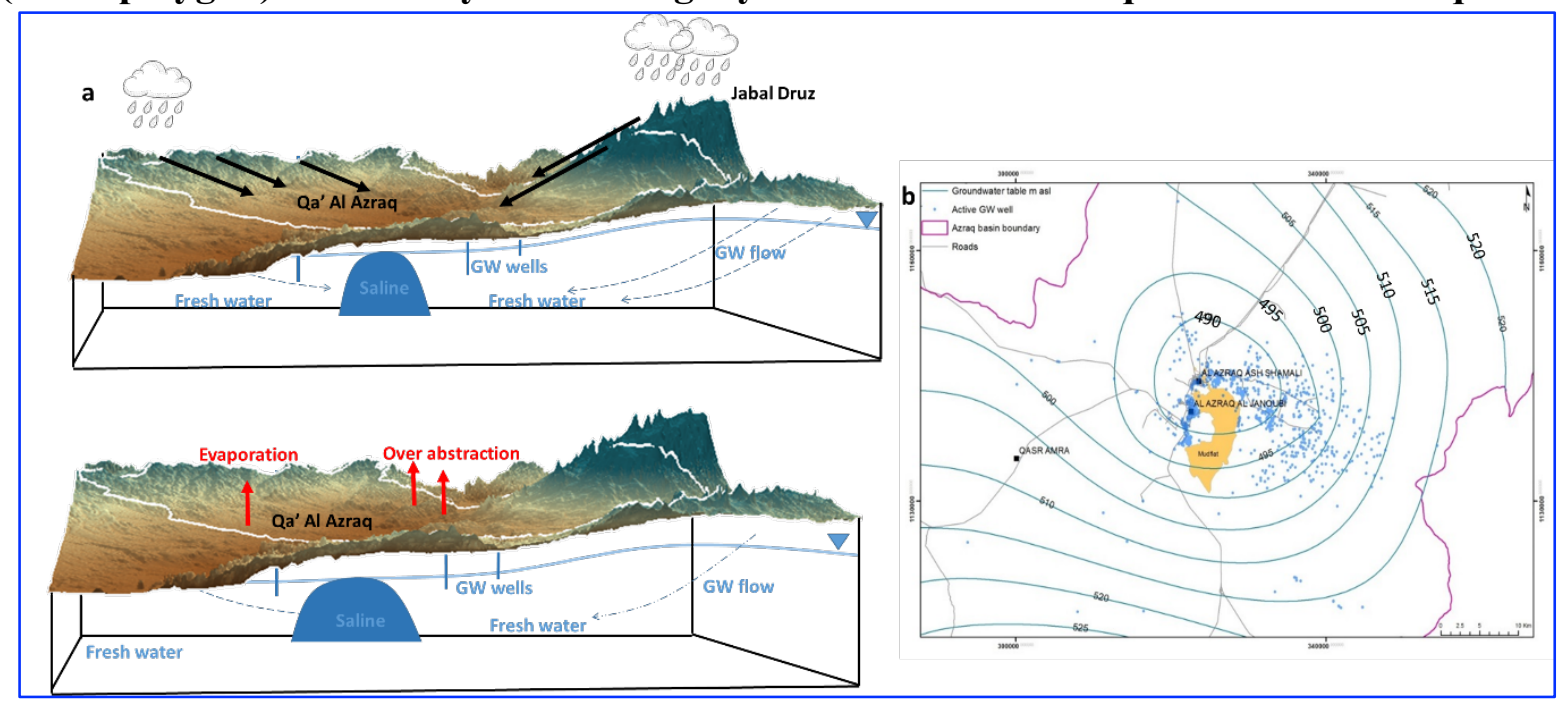

Fig. 4. (a) Simple schematic (not to scale) representation of the saline water intrusion following over abstraction and evaporation in the Qa Al-Azraq area. (b) Groundwater movement in the Azraq Basin (INWRDAM, 2019) 
Table 1. Major Aquifer units in the Azraq Basin

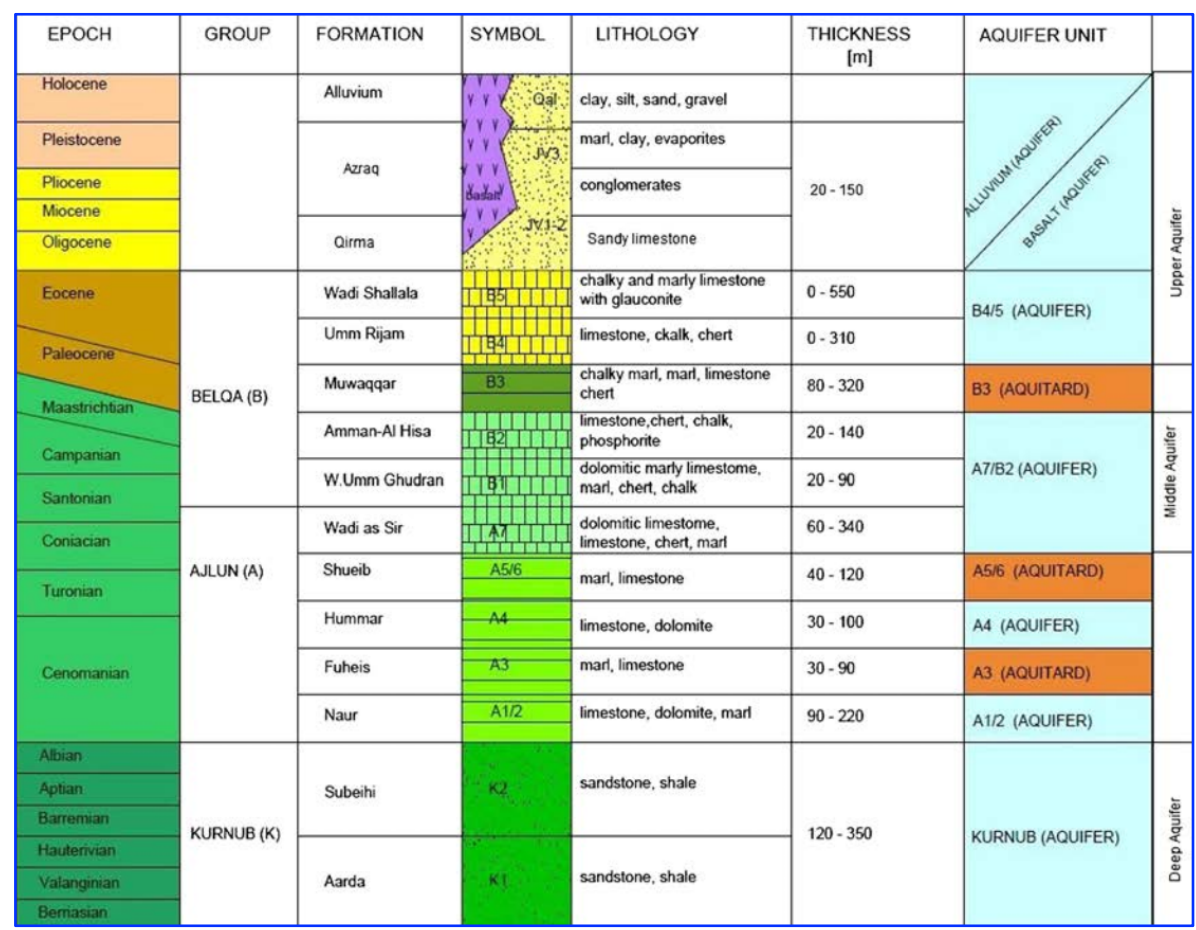

Furthermore, the groundwater geochemical evolution and water types were evaluated using a Piper (1944) trilinear diagram and a Durov (1948) plot (Aquachem version 3.7). A Piper diagram is a multidimensional plot in which the milli-equivalent percentage concentrations of major cations $\left(\mathrm{Ca}^{2+}, \mathrm{Mg}^{2+}, \mathrm{Na}^{+}\right.$, and $\left.\mathrm{K}^{+}\right)$and anions $\left(\mathrm{HCO}_{3}{ }^{-}, \mathrm{SO}_{4}{ }^{2-}\right.$, and $\left.\mathrm{Cl}^{-}\right)$are plotted in two triangular slots, which are finally projected into the central diamond field. On the other hand, a Durov diagram is a compound plot composed of two ternary diagrams in which the milliequivalent percentage of cations and anions of interest is plotted against each other, at the sides of a central rectangular, a biplot of total cation and total anion concentrations. The two diagrams primarily indicate similarities and differences within water samples and cluster them into groups. The Wilcox diagram, which has been widely used to classify water based on sodium adsorption ratio (SAR) and salinity hazard for agricultural use, was also used to further classify the samples. An elevated salinity causes a reduction in the osmotic activity of plants and affects the absorption of nutrients and water from the soil (Saleh et al., 1999). SAR can be calculated through the following formula (Karanth, 1987):

$$
S A R=\frac{N a^{+1}}{\left\{\left(C a^{+2}+M g^{+2}\right) / 2\right\}^{0.5}}
$$

If groundwater is rich in sodium and poor in calcium, the cation exchange system will witness sodium enrichment, which can destroy the soil structure, owing to the dispersion of clay particles (Singh et al., 2004). To further explain the water genesis, saturation indices (SI) were calculated because the potential for a chemical reaction to happen can be determined by 
the chemical equilibrium of the water with the mineral phases. SI are generally used to indicate if the groundwater is in thermodynamic equilibrium, undersaturated, or oversaturated with respect to certain solid phases (Grobe and Machel, 2002). SI can be expressed as log (IAP/Keq) (Drever, 1997), where IAP means ionic activity product and Keq stands for mineral equilibrium constant at a given temperature. Accordingly, if SI is equal to zero, then the water is in equilibrium with respect to the calculated mineral phase; if the value of SI is negative (less than zero), the water is undersaturated with respect to the mineral phase, and it will dissolve the mineral phase to reach the equilibrium; and if SI is positive (greater than zero), then the water system is oversaturated, and mineral precipitation is possible. The results of the hydrochemical evaluation were linked to the aquifer nature in the Qa' Al-Azraq and the presumable saline water body to explain the variations in salinity, and the role of the water/rock interactions.

Table 2. Groundwater samples locations and GW wells characteristics

\begin{tabular}{|c|c|c|c|c|c|c|c|c|c|}
\hline $\begin{array}{c}\text { Sample } \\
/ \\
\text { GW } \\
\text { well } \\
\end{array}$ & Pal_N & Pal_E & $\begin{array}{l}\text { Well } \\
\text { depth }\end{array}$ & Aquifer & $\begin{array}{c}\text { Sample } \\
/ \\
\text { GW } \\
\text { well }\end{array}$ & Pal_N & Pal_E & $\begin{array}{l}\text { Well } \\
\text { depth }\end{array}$ & Aquifer \\
\hline S1 & 1151452 & 321831 & 47 & $\begin{array}{l}\text { Alluvium } \\
\text { and B4 }\end{array}$ & S21 & 1140077 & 334303 & 50 & $\begin{array}{c}\text { Alluvium and } \\
\text { basalt }\end{array}$ \\
\hline S2 & 1172600 & 327800 & 56 & $\begin{array}{l}\text { B4 and } \\
\text { Basalt }\end{array}$ & S22 & 1130033 & 316420 & 50 & $\begin{array}{c}\text { Alluvium and } \\
\text { basalt }\end{array}$ \\
\hline S3 & 1151201 & 321234 & 38 & Alluvium & S23 & 1142121 & 329178 & 50 & B4 and Basalt \\
\hline S4 & 1146675 & 305590 & 67 & $\begin{array}{l}\text { B4 and } \\
\text { Basalt }\end{array}$ & S24 & 1136971 & 322548 & 45 & $\begin{array}{l}\text { Alluvium and } \\
\text { B4 }\end{array}$ \\
\hline S5 & 1145300 & 325300 & 57 & $\begin{array}{c}\text { B4 and } \\
\text { Basalt }\end{array}$ & S25 & 1144276 & 331578 & 38 & $\begin{array}{c}\text { Alluvium and } \\
\text { B4 }\end{array}$ \\
\hline S6 & 1150322 & 322125 & 60 & $\begin{array}{l}\text { B4 and } \\
\text { Basalt }\end{array}$ & S26 & 1146925 & 321169 & 115 & B4 \\
\hline S7 & 1149357 & 323246 & 64 & $\begin{array}{c}\text { B4 and } \\
\text { Basalt }\end{array}$ & S27 & 1143889 & 324645 & 95 & B4 \\
\hline S8 & 1149162 & 322415 & 92 & B4 & S28 & 1139736 & 322359 & 88 & B4 \\
\hline S9 & 1141920 & 321051 & 50 & $\begin{array}{l}\text { Alluvium } \\
\text { and basalt }\end{array}$ & S29 & 1140137 & 323571 & 45 & $\begin{array}{c}\text { Alluvium and } \\
\text { B4 }\end{array}$ \\
\hline S10 & 1144611 & 327699 & 50 & $\begin{array}{c}\text { Alluvium } \\
\text { and basalt }\end{array}$ & S30 & 1140451 & 323173 & 65 & B4 and Basalt \\
\hline S11 & 1140890 & 344466 & 68 & $\begin{array}{c}\text { B4 and } \\
\text { Basalt }\end{array}$ & S31 & 1107619 & 341329 & 73 & $\mathrm{~B} 4$ \\
\hline S12 & 1129720 & 320150 & 90 & B4 & S32 & 1144520 & 325610 & 80 & B4 \\
\hline S13 & 1140090 & 336626 & 95 & $\mathrm{~B} 4$ & S33 & 1143971 & 323463 & 48 & $\begin{array}{c}\text { Alluvium and } \\
\text { basalt }\end{array}$ \\
\hline S14 & 1182180 & 300580 & 67 & $\begin{array}{c}\text { B4 and } \\
\text { Basalt }\end{array}$ & S34 & 1142233 & 322832 & 55 & B4 and Basalt \\
\hline S15 & 1144556 & 328174 & 61 & $\begin{array}{c}\text { B4 and } \\
\text { Basalt }\end{array}$ & S35 & 1140303 & 323123 & 28 & Alluvium \\
\hline S16 & 1148354 & 321210 & 48 & $\begin{array}{l}\text { Alluvium } \\
\text { and basalt }\end{array}$ & S36 & 1143393 & 327168 & 37 & Alluvium \\
\hline S17 & 1150518 & 321488 & 55 & $\begin{array}{l}\text { B4 and } \\
\text { Basalt }\end{array}$ & S37 & 1140806 & 328357 & 49 & $\begin{array}{c}\text { Alluvium and } \\
\text { basalt }\end{array}$ \\
\hline S18 & 1144226 & 326311 & 105 & B4 & S38 & 1144123 & 325775 & 35 & Alluvium \\
\hline S19 & 1142247 & 334589 & 47 & $\begin{array}{l}\text { Alluvium } \\
\text { and B4 }\end{array}$ & & & & & \\
\hline S20 & 1138480 & 321790 & 70 & B4 & & & & & \\
\hline
\end{tabular}


Table 3. GW quality of the Qa' Al-Azraq samples (mg/l)

\begin{tabular}{|c|c|c|c|c|c|c|c|c|c|c|}
\hline & $E C$ & pn & a & $\mathrm{Mg}$ & Nod & n & u & $\mathrm{CCO}_{3}$ & $\mathrm{SO}_{4}$ & \\
\hline & 395 & 8.30 & .935 & 7.6 & 9.565 & 28 & 47.,395 & 113.765 & 28.32 & 3.5. \\
\hline & & & 6.61 & 2.19 & & 22 & 3.67 & 105.53 & 7.52 & 7.6 \\
\hline & & & 18 & & & & 10 & 129.93 & 31.2 & 2.6 \\
\hline & & & 26 & 12.28 & & & 75.97 & 138.47 & 44.64 & \\
\hline & re & & & 31.37 & & & 129.22 & 101.87 & $m$ & 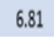 \\
\hline & 700 & 0.528 & $6 \sin$ & 11.915 & 97.405 & 7.235 & 1222.835 & 120.78 & 53.0 & 1.6 \\
\hline & 774 & & & & & & & 128 & 80.16 & 12.6 \\
\hline & & & & 14.71 & & & דיר 1 & & & \\
\hline & 921.5 & & & & & & 1.J.JoJ & 129.93 & & \\
\hline 510 & 1140 & & 31.46 & 17.27 & 154.33 & 3 & .1 & 143.35 & 79.68 & 0 \\
\hline 511 & 1146 & & & & & 12.51 & 143.42 & 200 & & \\
\hline$\$ 12$ & 1159 & & & & & & 177.15 & & & 8.4 \\
\hline S1: & 1177 & 7.7 & 73 & 32.47 & 104.42 & 21 & 182.83 & 213.5 & 120.48 & 2.1 \\
\hline 514 & 1191 & $810^{\circ}$ & 62.73 & 58 & אור & 0.56 & 252.05 & 045 & 832 & 26.2 \\
\hline S15 & 126 & & 31.06 & 16.05 & 189.06 & 8.21 & .47 & 157.99 & 87.36 & 5.04 \\
\hline 516 & 13 & & 38.48 & 23. & & 03 & .53 & 129.93 & 96.48 & 0.2 \\
\hline S17 & 140 & $8 . C$ & & 22.2 & & 8.99 & 375.24 & 122 & 3779.04 & 7.68 \\
\hline 31 & 1633 & & 43.29 & 19.7 & 254.15 & 12.12 & 358.55 & 175.68 & 115.68 & 6.29 \\
\hline
\end{tabular}

\begin{tabular}{|c|c|c|c|c|c|c|c|c|c|c|}
\hline nple & EC & $\mathrm{pHA}$ & Ca & lg & $\mathrm{Na}$ & K & a & $\mathrm{CO}_{3}$ & $\mathrm{SO}_{4}$ & $\mathrm{NO}_{3}$ \\
\hline 419 & 160 & 704 & & 41.47 & 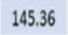 & 0. & 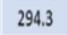 & .08 & 73.28 & 1047 \\
\hline & & 7.83 & 3.25 & 5.57 & .4 & 12.12 & 323.05 & 16.59 & 268.8 & .65 \\
\hline 21 & & 733 & 16252 & 70.65 & 42 & 13.69 & 110.03 & 93 & 462.72 & 647 \\
\hline 522 & & 1.44 & 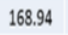 & 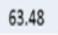 & 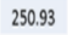 & 18.77 & 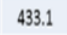 & 1.34 & 403.10 & 4.23 \\
\hline 523 & & 75 & 17.43 & 67.49 & & 29 & 5 & & 18 & .77 \\
\hline 524 & & 7.14 & & & 235.24 & 1575 & 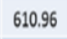 & 39 & 218.88 & 3.33 \\
\hline 525 & & 7.8 & 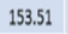 & 113.82 & ריר & 16.03 & 15.79 & & & 05 \\
\hline 526 & & 81 & & & & & & & & 4038 \\
\hline 7 & & 7.84 & 71.74 & 42. & & 18.38 & 7 & 99 & 14 & 0.89 \\
\hline 528 & 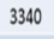 & 767 & 24 & 4426 & 2100 & 2542 & 743.02 & 254 & & 73 \\
\hline 525 & & & & & & & & & & 2.1 \\
\hline$\$ 30$ & 3660 & 7.81 & 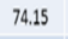 & & 143 & 25.81 & 4.49 & 218.99 & 304 & 18 \\
\hline §31 & & 7.41 & & & & & 7 & 182.39 & & 42.7 \\
\hline$\$ 32$ & & 7.85 & & & & & & 13 & 200.30 & 18.54 \\
\hline 23 & 5020 & 811 & 161 & 71.38 & 807.07 & 06 & 5 & 10896 & 358.56 & 11 \\
\hline$\theta$ & & טגר & & & & יתטי & 49.25 & בטריב & 080 & 5.09 \\
\hline & & 7. & & & & & & & & 33 \\
\hline$=$ & & 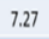 & 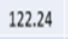 & 年 & 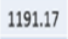 & . & 年 & 年 & 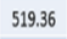 & \\
\hline$=$ & & 7.48 & 145.23 & 16 & 75.02 & 15 & 87.84 & 196.42 & 290.88 & 14.05 \\
\hline 30 & 500 & 7.41 & 9.64 & 1.45 & 19.44 & 74.78 & 532.18 & 92.76 & 750.08 & \\
\hline
\end{tabular}

Table 4. Descriptive statistics for the GW parameters

\begin{tabular}{|c|c|c|c|c|c|c|c|c|c|c|}
\hline & EC & pH & $\mathrm{Ca}$ & $\mathrm{Mg}$ & $\mathrm{Na}$ & K & $\mathrm{Cl}$ & $\mathrm{HCO}$ & SO4 & NO3 \\
\hline Min. & 395 & 7.14 & 6.61 & 2.19 & 49.22 & 2.74 & 43.67 & 74.42 & 28.32 & 0.2 \\
\hline 1st Qu. & 1142 & 7.678 & 31.16 & 20.14 & 109.59 & 8.21 & 178.26 & 126.27 & 81.96 & 2.295 \\
\hline Median & 1756 & 7.85 & 72.75 & 42.98 & 211.03 & 12.9 & 366.89 & 179.03 & 178.08 & 4.755 \\
\hline Mean & 3289 & 7.873 & 89.15 & 54.84 & 524.57 & 20.45 & 855.69 & 184.53 & 355.7 & 7.713 \\
\hline 3rd Qu. & 3572 & 8.154 & 121.04 & 66.49 & 517.44 & 23.76 & 814.28 & 213.35 & 319.2 & 8.258 \\
\hline Max. & 35500 & 8.74 & 319.64 & 301.45 & 7619.44 & 174.78 & 11532.18 & 527.65 & 3779.04 & 42.7 \\
\hline Std. Dev. & 5606.853 & 0.353474 & 71.42307 & 54.97378 & 1206.479 & 27.68172 & 1835.155 & 84.00075 & 639.6264 & 9.54853 \\
\hline
\end{tabular}

\section{RESULTS}

There is a strong correlation between $\mathrm{EC}$ and $\mathrm{Mg}, \mathrm{Na}, \mathrm{K}$, and $\mathrm{Cl}$ (Table5), suggesting that those elements seem to control the elevated or lowered salinity based on the groundwater content at each sampling site.

Table 5. Correlation matrix for the groundwater water parameters

\begin{tabular}{|c|c|c|c|c|c|c|c|}
\hline & EC & Calcium & Magnesium & Potassium & Bicarbonat & Sulfate & Nitrate \\
\hline EC & 1.00 & & & & \\
\hline Calcium & 0.65 & 1.00 & & & & \\
\hline Magnesium & 0.86 & 0.89 & 1.00 & & \\
\hline Sodium & 0.99 & 0.59 & 0.80 & & & \\
\hline Potassium & 0.99 & 0.62 & 0.82 & 1.00 & & \\
\hline Bicarbonat & 0.20 & 0.31 & 0.18 & 0.25 & 1.00 & & \\
\hline Sulfate & 0.37 & 0.30 & 0.33 & 0.35 & 0.05 & 1.00 & \\
\hline Nitrate & 0.00 & 0.44 & 0.32 & -0.03 & -0.13 & 0.13 & 1.00 \\
\hline Chloride & 1.00 & 0.63 & 0.85 & 0.98 & 0.16 & 0.37 & -0.01 \\
\hline
\end{tabular}


This control was also identified by the principal component analysis (PCA) results. The elements explaining the majority of the chemical variability were recognized (Fig. 5). The PCA analysis indicates that about $57 \%$ of the elemental variance is derived from the primary eigenvector (PC1), while the second eigenvector (PC2) explains about $17 \%$ of this variability. Fig. 4 shows the contribution of the different anions and cations to the two dimensions (PC1 and $\mathrm{PC} 2$ ); it indicates that $\mathrm{Na}, \mathrm{Mg}, \mathrm{Cl}, \mathrm{Ca}$, and $\mathrm{K}$ contribute the most to the variance in the chemical composition of the samples as they are positively correlated with one another and with PC1, thus signifying the importance of salts in the composition of the Qa' Al-Azraq groundwater samples.

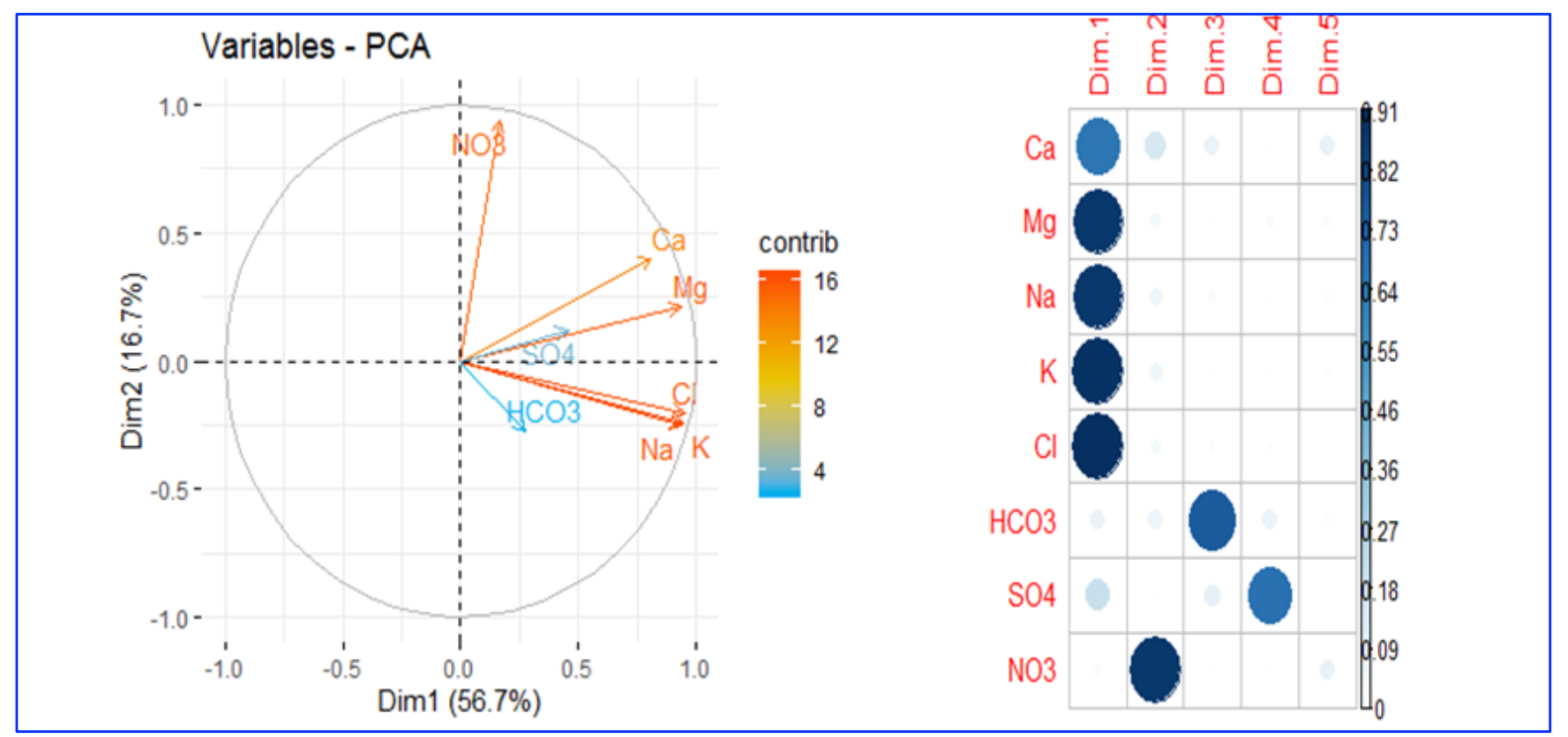

Fig. 5. Contribution of the main anions and cations to the total variance explained by Dim 1 (PC1) and Dim 2 (PC2)

These parameters are part of the evaporate sequence and contribute in much of the salt composition in the area. $\mathrm{Ca}$ is strongly correlated with $\mathrm{Mg}$, which is expected as they are both components of the $\mathrm{CaMg}_{2}$ calcium magnesium compound. $\mathrm{Mg}$ is also strongly correlated with $\mathrm{Na}, \mathrm{K}$, and $\mathrm{Cl}$. This is also expected as $\mathrm{Mg}$ forms the $\mathrm{MgCl}_{2}$ hydrate in brines. Additionally, there is a strong correlation between $\mathrm{Cl}$ and $\mathrm{K}$ as those two form the $\mathrm{KCl}$ salt. The positive correlation between $\mathrm{NO}_{3}$ and $\mathrm{PC} 2$ indicates the effect of agricultural practices in the area and the use of fertilizers (Burkart and Stoner, 2007; Ascott et al., 2017). On application to arable soils, the nitrogenous fertilizers are rapidly converted to a highly soluble nitrate form. When its quantity exceeds the immediate demand of the plants and the soil capacity to denitrify it, the excess nitrate leaches out from the root zone by water percolating through the soil profile and ultimately accumulates in groundwater, making it potentially unsafe for several uses. 


\section{Water Types}

The distribution of the Qa' Al-Azraq samples based on the Piper trilinear diagram (Fig. 6) shows that the majority of the samples plot in the $\mathrm{Na}^{+}-\mathrm{K}^{+}-\mathrm{Cl}^{-}-\mathrm{SO}_{4}^{2}$ hydrochemical facies slot, while the rest of the samples are in the $\mathrm{Ca}^{2+}-\mathrm{Mg}^{2+}-\mathrm{Cl}^{-}-\mathrm{SO}_{4}{ }^{2-}$ hydrochemical facies segment, indicating the dominance of alkali and alkaline earth (Piper, 1944). This clarifies the origin of sulfur in the waters of Azraq to be associated with gypsum dissolution (Ibrahim and El-Naqa, 2018). Furthermore, the samples plotted in the Piper diagram can be further categorized into seven fields, A to G, using Langguth (1966) classification for the Piper diagram. Accordingly, the samples plot into two types: "E," earth alkaline with prevailing $\mathrm{SO}_{4}$ and $\mathrm{Cl}$, and "G," alkaline water with prevailing $\mathrm{SO}_{4}$ and $\mathrm{Cl}$. This emphasizes the importance of $\mathrm{Na}^{+}, \mathrm{Cl}, \mathrm{K}^{+}, \mathrm{Cl}^{-}, \mathrm{SO}_{4}{ }^{2} \mathrm{Ca}^{2+}$, and $\mathrm{Mg}^{2+}$ in the control over the composition and the hydrochemical facies of the Qa' Al-Azraq groundwater samples.

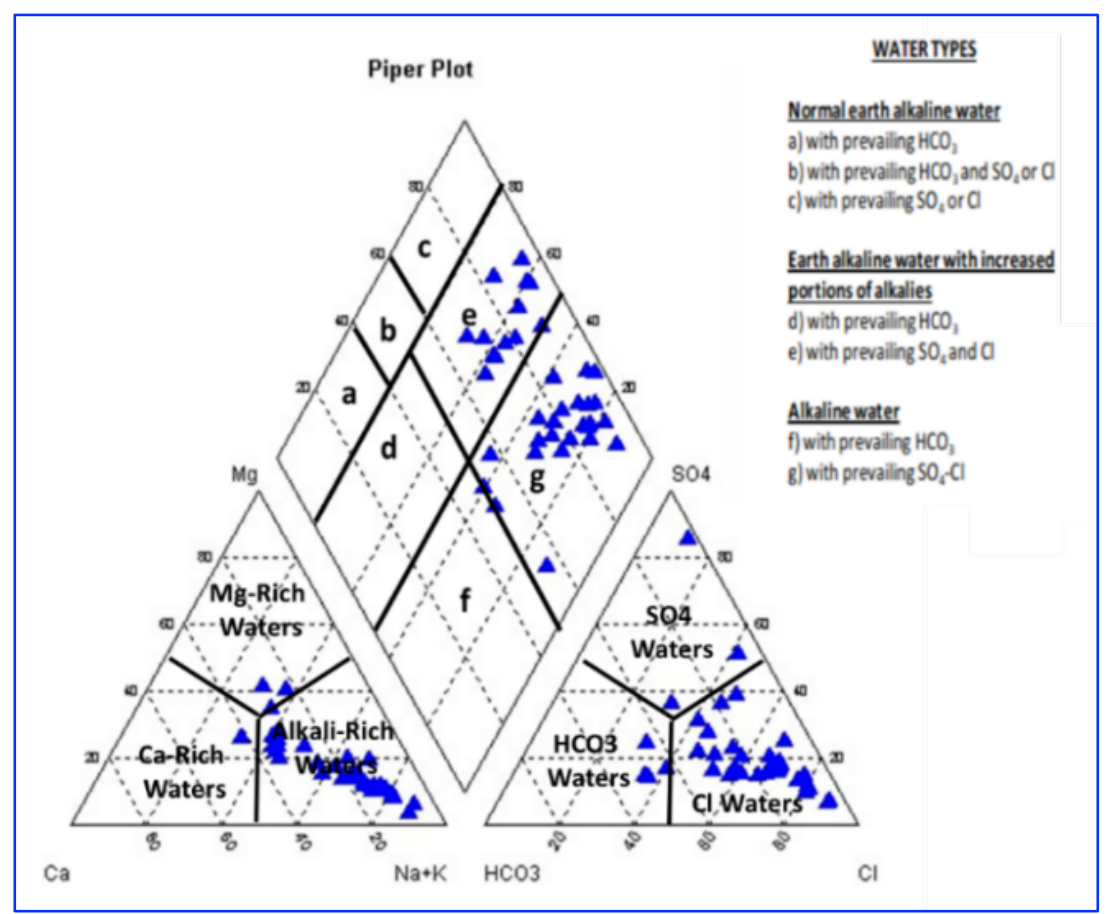

Fig. 6. Projection of the Qa' Al-Azraq groundwater samples in a Piper trilinear diagram (Langguth. 1966)

On the other hand, the major chemical composition of the samples was plotted on a Durov diagram (Durov, 1948) (Fig. 7) in an attempt to explain specific geochemical processes that could have affected the groundwater genesis. The presence of mixed water types in the study area was also supported by the Durov plot results. The Qa' Al-Azraq results show that the mixed geochemical processes occur. The samples plot in segments 2, 3, 5, and 6 (Table 6) reflect the presence of dissolution or mixing that can be explained by fresh recent water recharge exhibiting this process (Lloyd and Heathcoat, 1985) and the irrigation return flows, indicating 
a high impact of agriculture on the groundwater system in irrigated areas. Furthermore, a reverse ion exchange process was documented, where $\mathrm{Na}$ and $\mathrm{Cl}$ are dominant. The results of the Piper and Durov diagrams agree with the PCA results, where "the elements" are proven to dominate over the composition and the genesis of the Qa' Al-Azraq groundwater samples. Also, as documented in the previous research and as noted in the fieldwork of this study, agricultural practices are common and have been practiced for decades in the study area. Accordingly, the sodium hazard for irrigation water was assessed using a Wilcox diagram (Wilcox, 1955).

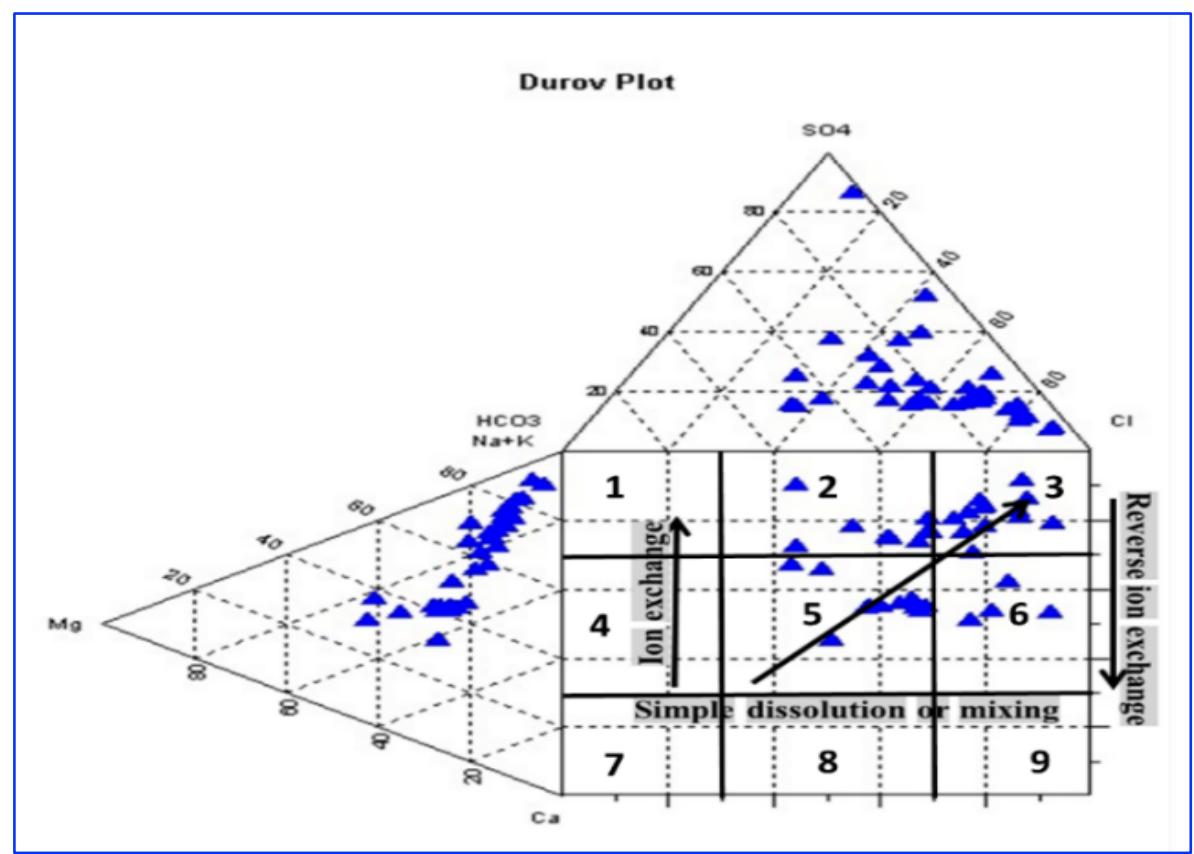

Fig. 7. Azraq Basin groundwater samples Durov plot depicting hydrochemical processes involved (Lloyd \& Heathcoat, 1985)

Table 6. Classification of water based on a Durov diagram (Lloyd \& Heathcoat, 1985)

\begin{tabular}{|c|c|}
\hline Sl. No & Water Types \\
\hline 1 & $\mathrm{HCO}_{3}$ and $\mathrm{Ca}$ dominant, frequently indicates recharging waters in limestone, sandstone, and many other aquifers \\
\hline 2 & $\begin{array}{l}\text { This water type is dominated by } \mathrm{Ca} \text { and } \mathrm{HCO}_{3} \text { ions. Association with dolomite is presumed if } \mathrm{Mg} \text { is significant. } \\
\text { However, those samples in which } \mathrm{Na} \text { is significant, an important ion exchange is presumed }\end{array}$ \\
\hline 3 & $\begin{array}{l}\mathrm{HCO}_{3} \text { and } \mathrm{Na} \text { are dominant, normally indicates ion exchanged water, although the generation of } \mathrm{CO}_{2} \text { at depth can } \\
\text { produce } \mathrm{HCO}_{3} \text { where } \mathrm{Na} \text { is dominant under certain circumstances }\end{array}$ \\
\hline 4 & $\begin{array}{l}\mathrm{SO}_{4} \text { dominates, or anion discriminant and } \mathrm{Ca} \text { dominant, } \mathrm{Ca} \text { and } \mathrm{SO}_{4} \text { dominant, frequently indicates recharge } \\
\text { water in lava and gypsiferous deposits, otherwise mixed water or water exhibiting simple dissolution may be } \\
\text { indicated. }\end{array}$ \\
\hline 5 & No dominant anion or cation, indicates water exhibiting simple dissolution or mixing. \\
\hline 6 & $\begin{array}{l}\mathrm{SO}_{4} \text { dominant or anion discriminate and } \mathrm{Na} \text { dominant; is a water type that is not frequently encountered and } \\
\text { indicates probable mixing or uncommon dissolution influences. }\end{array}$ \\
\hline 7 & $\begin{array}{l}\mathrm{Cl} \text { and } \mathrm{Na} \text { dominant is frequently encountered unless cement pollution is present. Otherwise the water may result } \\
\text { from reverse ion exchange of } \mathrm{Na}-\mathrm{Cl} \text { waters. }\end{array}$ \\
\hline 8 & $\begin{array}{l}\mathrm{Cl} \text { dominant anion and } \mathrm{Na} \text { dominant cation, indicate that the ground waters be related to reverse ion exchange of } \\
\mathrm{Na}-\mathrm{Cl} \text { waters. }\end{array}$ \\
\hline 9 & $\mathrm{Cl}$ and $\mathrm{Na}$ dominant frequently indicate end-point down gradient waters through dissolution \\
\hline
\end{tabular}


Fig. 8 shows the Wilcox diagram for the Qa' Al-Azraq groundwater samples, indicating that the samples are in the medium to very high salinity slots with the majority in the high salinity slot. In terms of alkalinity hazards, most of the samples are in the low and medium alkali hazard zone, while few samples show high to very high alkali hazards.

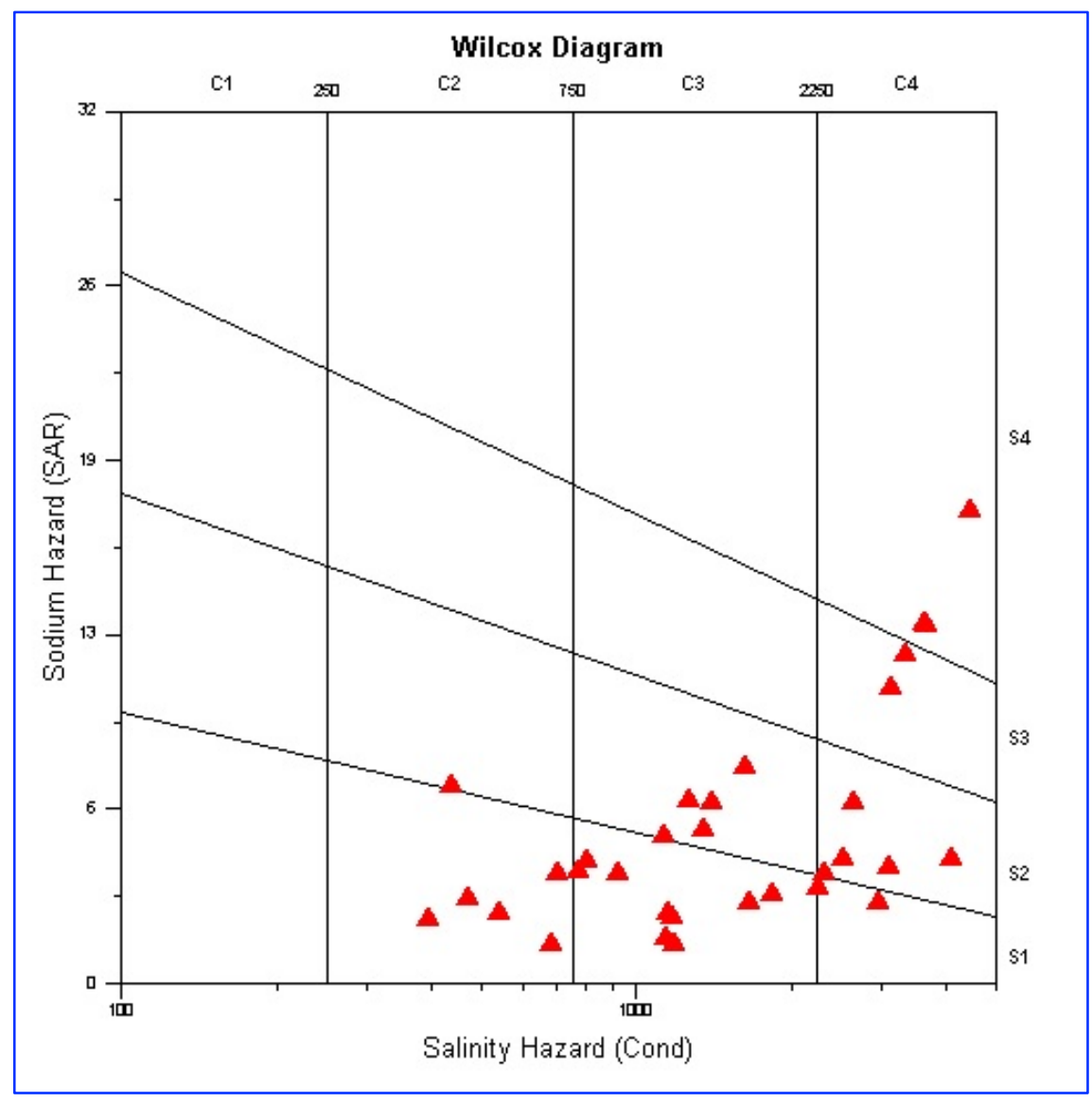

Fig. 8. Azraq Basin groundwater samples Wilcox classification

The SI for the GW samples in the area were calculated using the laboratory and field measurements and the PHREEQC interactive software (Charlton et al., 1997). Accordingly, the Qa' Al-Azraq groundwater is generally oversaturated with respect to aragonite $\left(\mathrm{CaCO}_{3}\right)$, calcite $\left(\mathrm{CaCO}_{3}\right)$, and dolomite $\left(\mathrm{CaMg}\left[\mathrm{CO}_{3}\right]_{2}\right)$ indicated by the excess input of $\mathrm{Mg}$ and $\mathrm{Ca}$ ions from the rock-water interactions, while anhydrite $\left(\mathrm{CaSO}_{4}\right)$, halite $(\mathrm{NaCl})$, and gypsum $\left(\mathrm{CaSO}_{4} \cdot 2 \mathrm{H}_{2} \mathrm{O}\right)$ are generally undersaturated, indicating that the sulfated portion of the groundwater can be attributed to gypsum dissolution. Also, irrigation water dissolves carbonates from the soil profile to the groundwater, leading to a case of oversaturation. While halite is one of the last minerals that crystallize in the soil after irrigation, it is rarely formed because of excessive irrigation. 


\section{Groundwater Salinity}

The increased overexploitation of the groundwater resources in the Azraq area, especially during the last three decades, has led to a dramatic drop in the groundwater levels by more than $30 \mathrm{~m}$ in some groundwater wells (INWRDAM, 2019). This drop has been accompanied by increasing groundwater salinity, exceeding, in some wells, $3500 \mu \mathrm{S} / \mathrm{cm}$, which is the upper limit for irrigating salt semi-tolerant crops. One GW well in the Qa' Al-Azraq shows a salinity value of 35500 as observed in this study. Such damage to the fresh groundwater body as a result of saltwater disturbance is irreversible and requires tens to hundreds of years to recover if all the groundwater extraction is stopped immediately. Further pumping of the groundwater will certainly lead, in a few years, to the total deterioration of the whole aquifer in the area and to the damage of several hundred million cubic meters of good-quality groundwater by salinization. Accordingly, GW salinity was further investigated by using time series salinity measurements for monitoring wells in the study area over the period 1984-2017.

The identified annual increase in salinity was applied to the projection period and the interpolation of salinity values was done using a natural neighborhood model based on which groundwater salinity zones were defined. This mapping was done for the B4 aquifer, which holds fresh to brackish water in the area. Measured salinity values for the years 1990, 2000, 2010, and 2017, reflect an increasing trend in salinity starting from the eastern part of the basin and moving towards the west (Fig. 9). The development in salinity is influenced by several factors in the area, such as accelerated irrigated agricultural growth (Clarke et al., 2018).

Fig. 10 illustrates the simulated salinity trend forecast in GW monitoring wells in the area up to the year 2050. Accordingly, Fig. 11 shows that the simulated salinity for the year 2050, providing an alert for a rapid increase in the groundwater salinity, which will affect the whole groundwater system. This increasing trend in salinity can be attributed to several current acts and factors affecting the Azraq Basin. An increase over pumping associated with the decline in groundwater levels will pose threats to agricultural practices and even the domestic use of the groundwater. An increase in the groundwater salinity will result in the deterioration of the groundwater system, which will eventually affect the soil capability and the whole ecosystem. 


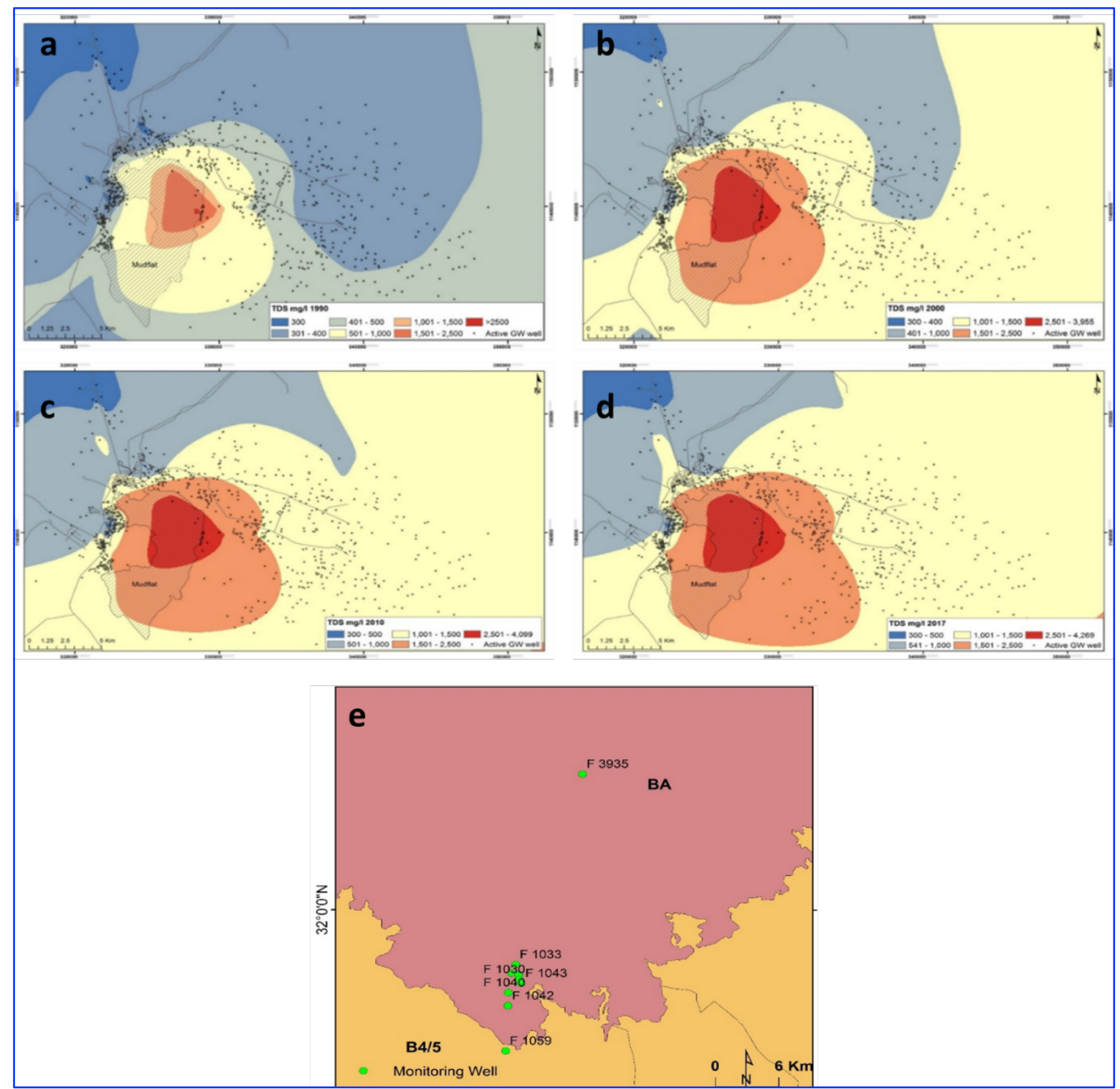

Fig. 9. TDS values for the Azraq Basin for the years (a) 1990 (b) 2000 (c) 2010 and (d) 2017 (e) Location of the GW monitoring wells 


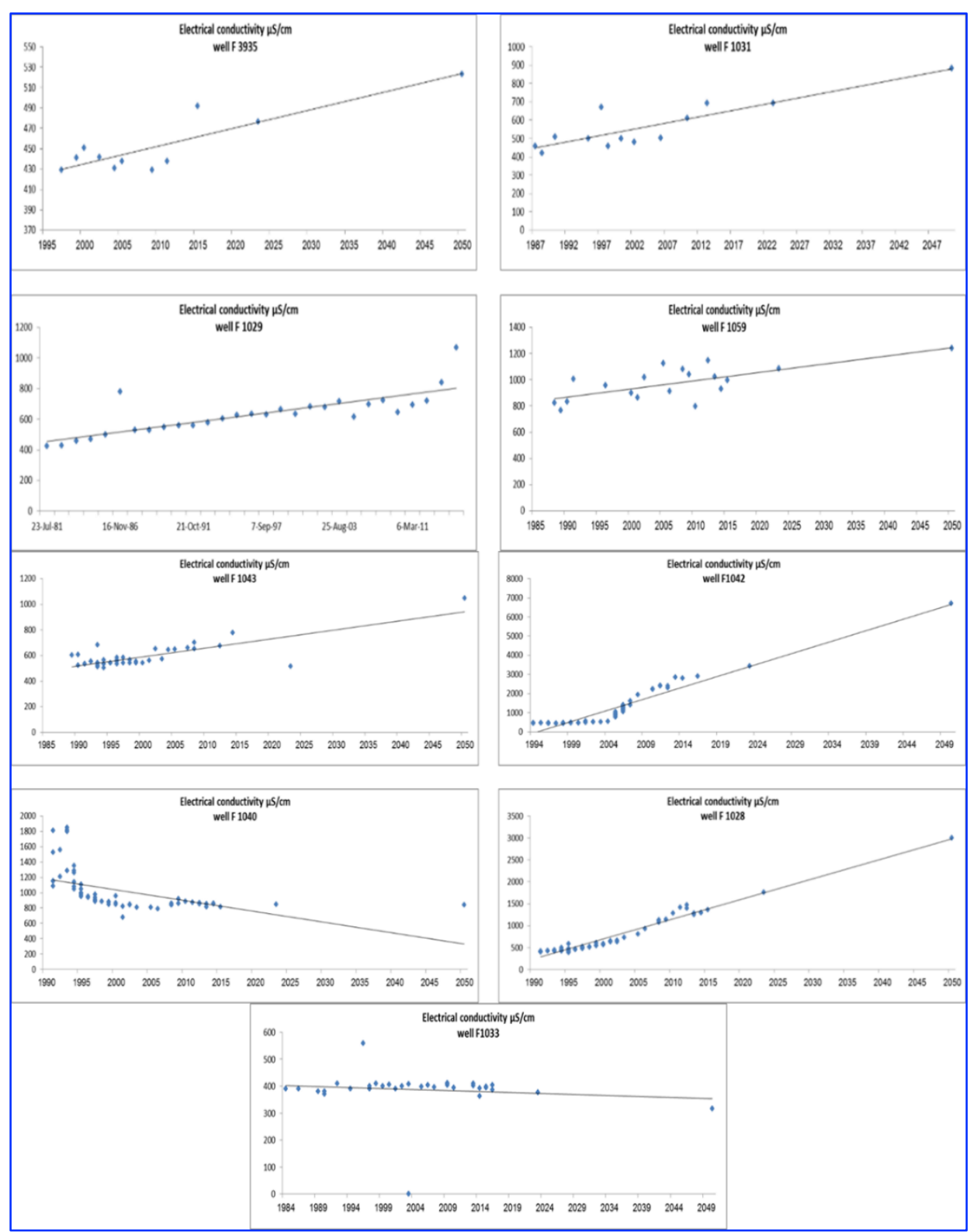

Fig. 10. Simulated salinity trends for monitoring GW wells in the Azraq Basin

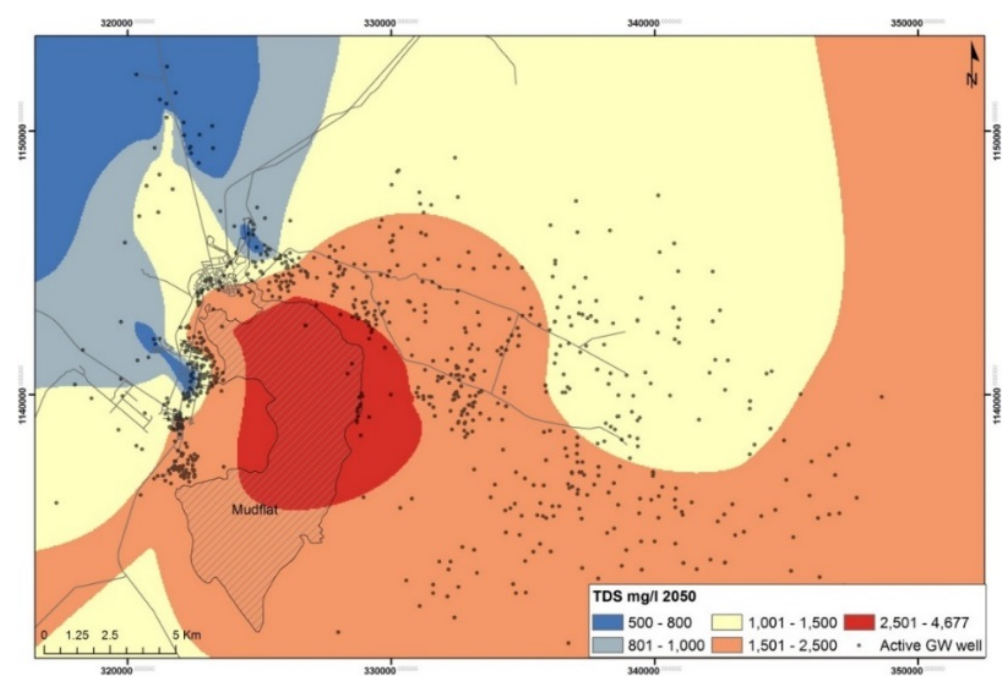

Fig. 11. Simulated salinity for the year 2050 


\section{CONCLUSIONS}

This study aims to evaluate the hydrochemical characteristics of the Azraq Basin groundwater. The presence of an underground saline water body in the Qa' Al-Azraq area has made this specific part of the basin of special interest for researchers. $38 \mathrm{GW}$ samples were collected from $38 \mathrm{GW}$ wells in order to understand the GW chemistry. The statistical analyses and the PCA results indicate that $\mathrm{Na}, \mathrm{Mg}, \mathrm{Cl}, \mathrm{Ca}$, and $\mathrm{K}$ are the main elements controlling the salinity variations in the studied GW wells.

This control was also identified by the principal component analysis (PCA) results. The elements explaining the majority of the chemical variability were recognized (Fig. 4). The PCA analysis indicates that about $57 \%$ of the elemental variance is derived from the primary eigenvector (PC1), while the second eigenvector (PC2) explains about $17 \%$ of this variability. Fig. 4 shows the contribution of the different anions and cations to the two dimensions (PC1 and $\mathrm{PC} 2$ ); it indicates that $\mathrm{Na}, \mathrm{Mg}, \mathrm{Cl}, \mathrm{Ca}$, and $\mathrm{K}$ contribute the most to the variance in the chemical composition of the samples as they are positively correlated with one another and with PC1, thus signifying the importance of salts in the composition of the Qa' Al-Azraq groundwater samples. Those parameters are part of the evaporate sequence and contribute to much of the salt composition in the area. $\mathrm{Ca}$ is strongly correlated with $\mathrm{Mg}$, which is expected as they are both components of the $\mathrm{CaMg}\left(\mathrm{CO}_{3}\right)_{2}$ calcium magnesium compound. $\mathrm{Mg}$ is also strongly correlated with $\mathrm{Na}, \mathrm{K}$, and $\mathrm{Cl}$. This is also expected as $\mathrm{Mg}$ forms the $\mathrm{MgCl}_{2}$ hydrate in brines. Additionally, there is a strong correlation between $\mathrm{Cl}$ and $\mathrm{K}$ as those two forms the $\mathrm{KCl}$ salt. Also, the projection of the results on the Piper diagram shows that the samples cluster within two water types: earth alkaline with prevailing $\mathrm{SO}_{4}$ and $\mathrm{Cl}$, and alkaline water with prevailing $\mathrm{SO}_{4}$ and $\mathrm{Cl}$. This emphasizes the importance of $\mathrm{Na}^{+}, \mathrm{Cl}^{-}, \mathrm{K}^{+}, \mathrm{Cl}^{-}, \mathrm{SO}_{4}^{2-}, \mathrm{Ca}^{2+}$, and $\mathrm{Mg}^{2+}$ in the control over the composition and the hydrochemical characteristics of the Qa' AlAzraq groundwater samples. The Durov diagram indicates that the presence of dissolution or mixing that can be explained by fresh recent water recharge accompanied by a reverse ion exchange process in which $\mathrm{Na}$ and $\mathrm{Cl}$ are prevailing, emphasizing the dominance of these elements over the composition and the genesis of the Qa' Al-Azraq groundwater samples.

The SI indicates a general oversaturation with respect to aragonite $\left(\mathrm{CaCO}_{3}\right)$, calcite $\left(\mathrm{CaCO}_{3}\right)$, and dolomite $\left(\mathrm{CaMg}\left[\mathrm{CO}_{3}\right]_{2}\right)$ as indicated by the excess input of $\mathrm{Mg}$ and $\mathrm{Ca}$ ions from the rock-water interactions, while anhydrite $\left(\mathrm{CaSO}_{4}\right)$, halite $(\mathrm{NaCl})$, and gypsum $\left(\mathrm{CaSO}_{4} \cdot 2 \mathrm{H}_{2} \mathrm{O}\right)$ are generally undersaturated indicating that the sulfated portion of the groundwater can be attributed to gypsum dissolution. These processes can be explained as the GW path in the 
aquifer moves through marl, evaporites and limestone and clay formations where the GW genesis and elemental composition can be altered and determined by the rock/water interactions and ion exchange processes.

Another determining factor in the elemental composition of the GW in the Qa' Al-Azraq is the anthropogenic activities, mainly the agricultural practices and over pumping. Agricultural practices are common and have been practiced for decades in the study area. The positive correlation between $\mathrm{NO}_{3}$ and $\mathrm{PC} 2$ indicates the effect of agricultural practices in the area and the use of fertilizers. The nitrogenous fertilizers are converted to a highly soluble nitrate form in soils. When its quantity exceeds the demand of the plants and the soil capacity to denitrify it, the excess leaches out from the root zone by water percolating through the soil profile and ultimately accumulates in groundwater.

The sodium hazard for irrigation based on Wilcox diagram indicates that the samples are in the medium to very high salinity slots with the majority in the high salinity slot and in the low and medium alkali hazard zone, while few samples show high to very high alkali hazards. Also, irrigation water dissolves carbonates from the soil profile to the groundwater, leading to a case of oversaturation. While halite is one of the last minerals that crystallize in the soil after irrigation, it is rarely formed because of excessive irrigation.

Considering the previously mentioned factors determining the chemistry of the Azraq GW and the continued overpumping and increasing anthropogenic, mainly agricultural, practices; the simulated salinity for the next 30 years shows alarming danger and requires immediate attention. This can be achieved, even if partially, by controlling the GW abstraction and the agricultural activities in the area.

\section{ACKNOWLEDGEMENTS}

The authors acknowledge that this work is part of a broader USAID LENS funded project entitled “A Plan to Revitalize Salt Production Industry in Azraq”. The authors also acknowledge that this work was supported by the Inter-Islamic Network on Water Resources Development and Management (INWRDAM), who supplied the data and facilitated the fieldwork. The authors are very grateful to the editor in chief Prof. Dr. Salih M. Awadh, the secretary of Journal Mr. Samir R. Hijab. and head of the technical editors Dr. Heba S. Al-Mimar for their great efforts and valuable comments.

\section{REFERENCES}

Ascott, M. J., Gooddy, D. C., and Wang, L., 2017. Global Patterns of Nitrate Storage in The Vadose Zone. Nat Commun 8, 1416.

Al-Karablieh, E., and Salman, A., 2016. Water Resources, Use and Management in Jordan- A focus on Groundwater. IWMI project report. 113p. 
Awadh, S. M., 2020. Al-Mimar, H. S, and Yaseen, Z. M., 2019. Ground water availability and water demand sustainability over the upper mega aquifers of Arabian Peninsula and West region of Iraq. Journal of Environment, Development and Sustainability, Springer, DOI 10.1007/s10668-019-00578-z.

Awadh, S. M., 2018. A preliminary assessment of the geochemical factors affecting groundwater and surface water quality around the rural communities in Al-Anbar, Western desert of Iraq. Environmental Earth Sciences, Springer, 77(3): 1-18.

Burkart, M. R., and Stoner, J. D., 2007. Nitrate in aquifers beneath agricultural systems. Water Science Technology, 56 (1): 59-69.

Clarke, D., Lázár, A. N., Saleh, A. F. M., and Jahiruddin, M. (2018). Prospects for Agriculture Under Climate Change and Soil Salinisation. In: Nicholls R., Hutton C., Adger W., Hanson S., Rahman M., Salehin M. (eds) Ecosystem Services for Well-Being in Deltas. Palgrave Macmillan, Cham

Drever, J. I., 1997. The Geochemistry of Natural Waters. Prentice-Hall, New Jersey, 436 P.

Durov, S. A., 1948. Natural Waters and Graphic Representation of Their Composition.

El-Naqa, A., Al-Momani, M., Kilani, S., and Hammouri, N., 2007. Groundwater deterioration of shallow groundwater aquifers due to overexploitation in Northeast Jordan. Clean Soil Air Water, 35: 156-166.

Grobe, M., and Machel, H. G., 2002. Saline groundwater in the Münsterland Cretaceous Basin, Germany: clues to its origin and evolution. Marine Petroleum Geology, 19:307-322.

Ibrahim, M. N., 2018, Assessing groundwater quality for drinking purpose in Jordan: Application of Water Quality Index, Journal of Ecological Engineering, 20:3.

Ibrahim, K. M., and El-Naqa, A. R., 2018. Inverse geochemical modeling of groundwater salinization in Azraq Basin, Jordan. Arabian Journal of Geosci, 11: 237.

Ibrahim, K. M., .1996. The Regional Geology of the Al Azraq Area. Geological Mapping Division, Natural Resources Authority, Jordan, 67 P.

Inter-Islamic Network on Water Resources Development and Management (INWRDAM), 2019. Revitalization of Azraq basin salt production, unpublished report.

Jirjees, S., Seeyan, S., and Fatah, K., 2020. climatic analysis for Pirmam area, Kurdistan region, Iraq. Iraqi Geological Journal, 53(E): 75-92.

Karanth, K. R., 1987. Groundwater Assessment Development and Management Tata McGraw Hill publishing company Ltd., New Delhi, 725P.

Langguth, H. R., 1966. Groundwater verhaltisse in Bereiech Des Velberter. Sattles. Der Minister Fur Eraehrung, Land Wirtsch Forste (pp. 127). Duesseldorf: NRW.

Lloyd, J. W., and Heathcoat, J. A., 1985.Natural Inorganic Chemistry in Relation to Groundwater. Clarendon Press, Oxford.

Möller, P., De Lucia, M., Rosenthal, E., Inbar, N., Salameh, E., Magri, F., and Siebert, C., 2020. Sources of salinization of groundwater in the Lower Yarmouk Gorge, East of the River Jordan, Water, 12:1291.

Charlton, S. R., Macklin, C. L, and Parkhurst, D. L., 1997. PHREEQCI; a graphical user interface for the geochemical computer program PHREEQC. U.S. Geological Survey.

Piper, A. M., 1944. A Graphic Procedure in the Geochemical Interpretation of Water-Analyses. Eos, Transactions American Geophysical Union, 25: 914-928.

Saleh, A., and AL-Ruwaih, F., and Shehata, M., 1999. Hydrogeochemical processes operating within the main aquifers of Kuwait. Journal Arid Environment, 42:195-209.

Singh, K. P., Malik, A., Mohan, D., and Sinha, S., 2004. Multivariate statistical techniques for the evaluation of spatial and temporal variations in water quality of Gomti River (India): a case study. Water Resource, 38(18):3980-3992.

Wilcox, L.V., 1955. Classification and use of irrigation waters. United States Department of Agriculture (USDA) Circular No. 939, Washington DC, USA. 19p.

Yaseen, Z. M., Awadh, S. M., Ahmad, S., and Shamsuddin, S., 2018. Complementary data-intelligence model for river flow simulation, Journal of Hydrology, Elsevier, 567: 180-190. 